DOI 10.31558/2519-2949.2018.1.14

УДК $328.188(100)(043.5+043.5)$

\author{
Попазогло В. С., Державний заклад «Південноукраїнський національний \\ педагогічний університет імені К. Д. Уиинського»
}

\title{
ДЕСТРУКТИВНІ НЕФОРМАЛЬНІ ПОЛІТИЧНІ ІНСТИТУТИ: ФОРМИ ПРОЯВУ ТА МЕХАНІЗМИ ПРОТИДІЇ
}

Досліджуються неформальні інститути політики деструктивного різновиду. Основними їх видами визначено інститути політичного непотизму, кронізму, фаворитизму, корупиії, патронклієнтизму, клановості та ін. Запропоновано авторське розуміння основних видів неформальних деструктивних інститутів крізь призму методології неоінституціоналізму. Проаналізовано основні причини виникнення та укоріненості інститутів цъього виду. Розкрито особливості неформальної інституціалізації політики держав із відмінним за рівнем впливу на політику деструктивних інститутів: латиноамериканських (Аргентина, Бразилія та Перу), азійських (найперше, південно-східних) держав, США та держав-учаснищь СС. Визначено такі групи механізмів протидії деструктивній інституиіалізації політики, як запобіжні (превентивні, спрямовані на недопущення інституціалізації деструктивних неформальних інститутів політики); протидії (викорінення, мінімізація уже інституціалізованих неформальних практик у політиці).

В аналізі особливу увагу приділено пострадянським державам. Досліджено прояви неформальної інституціалізації держав Південного Кавказу. Розкрито вплив неформальних підривних інститутів на політичні системи Азербайджану, Вірменії та Грузї. Вказано на основні відмінності в імплементаиії підривних інститутів у державах регіону. Визначено умови, які сприяють або ж перешкоджають укоріненості неформальних підривних інститутів у політичну систему пострадянських держав Південного Кавказу. У статті порівнюються неформальні політичні інститути деструктивного різновиду в Білорусі та Росії. 3 'ясовано спільні та відмінні характеристики неформальної інституціалізації у цих державах. Визначено спільні характеристики прояву підривних неформальних політичних інститутів у Білорусі та Росії: визначальна роль підривних неформальних інститутів у політиці обох держав; взаємодоповнюваність формальних та неформальних деструктивних політичних інститутів; неоавторитаризм, як чинник, який сприяе деструктивній інституиіалізаиії; наявність кланової управлінської системи, розвинених патрон-клієнтських мереж; домінування неформальних клієнтельних зв'язків над елементами громадянського суспільства; рекрутування еліт на засадах клієнтизму.

Ключові слова: політичні інститути, неформальні деструктивні інститути, непотизм, кронізм, корупція, клановість, фаворитизм, патрон-клієнтизм.

На політичний процес впливають не лише формальні, але й неформальні інститути деструктивного різновиду. Їх виникнення $є$ результатом слабкості формальних і конструктивних неформальних інститутів (на взірець громадянського суспільства). Руйнівний вплив таких інститутів зумовлює неформальну інституціалізацію (систематичну руйнацію інститутів непідривної діï), деформалізацію (заміщення формальних інститутів, неформальною інституціалізацією). Деструктивні неформальні інститути формують рентоорієнтований тип поведінки політичних акторів, конструюють нецивілізовані механізми й алгоритми відтворення влади. Це становить істотну небезпеку для поступального розвитку сучасної держави, що актуалізує науковий аналіз з метою випрацювання механізмів протидії інститутами такого типу.

Комплексного дослідження неформальної деструктивної інституціалізації на прикладі держав світу проведено у вітчизняній політичній науці не було, але наявна низка розвідок, яка започатковує розв'язок проблеми. Відзначимо доробок зарубіжних авторів (В. Гельман, А. Іскандарян, А. Круасан, С. Левітскі, В. Меркель, К. Монтанер, Д. С. Норт, С. Патрушев, Г. Хейл, Г. Хелмке та ін.) та вітчизняних дослідників (Г. Зеленько, М. Кармазіна, Г. Кліпкова, О. Крисенко, Ю. Мацієвський, Є. Перегуда, О. Рибій, О. Стойко, М. Чабанна, О. Фісун та ін.).

На нашу думку, деструктивні (підривні) неформальні політичні інститути - це різновид неформальних політичних інститутів, спрямованих на руйнування політичної системи, зокрема

(C) Попазогло В. С., 2018 
формальних, а також конструктивних неформальних інститутів. Основними видами інститутів цієї групи визначаємо інститути політичного непотизму, кронізму, фаворитизму, корупції, патронклієнтизму, клановості та ін. Запропонуємо авторську концептуалізацію основних видів неформальних деструктивних інститутів крізь призму методології неоінституціоналізму:

- інститут політичного непотизму - деструктивний неформальний політичний інститут, який проявляється в здійсненні державними, політичними високопосадовцями латентної функції «соціального ліфта» для певного кола осіб (родинне коло), забезпечуючи їм в обхід прозорих процедур певні преференції (призначення на посади, місце у прохідній частині виборчого списку тощо);

- інститут політичного кронізму - деструктивний неформальний політичний інститут, який полягає у посадовому просуванні чи наданні інших преференцій суб'єктам державотворчого, політичного процесу на підставі їх приналежності до певного дружнього кола всупереч принципам прозорості, транспарентності;

- інститут політичного фаворитизму - деструктивний неформальний політичний інститут, який полягає у наданні необгрунтованих преференцій особі чи групі осіб (акторів державотворчого, політичного процесу) з розрахунком на взаємні послуги;

- інститут політичної корупції - деструктивний неформальний політичний інститут, який забезпечує неправомірне латентне використання ресурсів влади, приватизацію публічних ресурсів суб'єктами державотворчого, політичного процесу з корисливих мотивів у приватних інтересах чи інтересах вузьких груп;

- інститут політичного патрон-клієнтизму - деструктивний неформальний політичний інститут, який полягає у встановленні відносин панування-підпорядкування між особами 3 різними ресурсними можливостями, зазвичай не поєднаними родинними стосунками, одні 3 яких забезпечують іншим протекцію в обмін на їх лояльність і політичну підтримку;

- інститут політичної клановості - деструктивний неформальний інститут, який полягає у наявності політичної еліти 3 ієрархічною (пірамідальною), закритою структурою, утвореною на основі одного чи кількох об'єднуючих чинників (кровна спорідненість, територіальність, бізнесінтереси, політичні цілі) задля кооперації в інтересах посилення безпеки, стабільності певної групи (корпоративна партикулярна спрямованість).

Вивчення неформальної деструктивної інституціалізації на пострадянському просторі дозволяє констатувати чітку увиразненість інститутів підривного типу в усіх незалежних державах, які були досліджені (центральноазійські держави, держави Південного Кавказу, Україна, Білорусь та Росія) за наявності окремих характерних особливостей у кожній із них:

- центральноазійські держави створюють радше не моделі модернізації, а демодернізації; діючі системи особистих зв'язків свідчать про традиціоналізм та архаїчність політики. Вони різняться домінуючим підривним інститутом (олігархічні групи в Казахстані, клани в Узбекистані, Таджикистані і под.). Присутніми є регіонально-кланові зв'язки та трайбалістичні практики. Формальні інститути співіснують із мережами заступницьких зв'язків родинно-кланового і феодально-клієнтського характеру [2, с. 7]. Патрон-клієнтська система є основним механізмом представництва інтересів різних груп населення центральноазійських держав;

- порівняння неформальної деструктивної інституціалізації політики Білорусі та Росії дозволяє вказати на спільні та відмінні характеристики. Спільне: визначальний характер деструктивних неформальних інститутів політики; взамодоповнюваність, взаємопереплетіння формальних i деструктивних неформальних інститутів; укоріненість патронатно-клієнтельних зв'язків. Відмінне: конституційне закріплення необмеженого переобрання глави держави (Білорусь) і неформальний інститут спадкоємця президентської влади (Росія); несформованість олігархату через жорсткий контроль глави держави (Білорусь) і великий вплив олігархії на прийняття важливих політичних рішень, фактичне олігархічне «захоплення влади» рентозорієнтованими економічними гравцями разом із неопатримоніальною бюрократією (Росія); відмінність обсягів політичної корупції (менший у Білорусі та системного характеру в Росії) та ін.;

- для держав Південного Кавказу характерна виражена політична традиційність i патріархальність, збереження кровно-родинних (кланових) відносин із певними відмінностями Азербайджану, Вірменії та Грузії. Їх особливості: а) Азербайджан як держава фасадної демократії визначальне місце у закритій, непрозорій політиці неформально відводить кланам (найперше клану Алієвих-Пашаєвих); громадський контроль за владою відсутній, спротив суспільства неформальним підривним інститутам незначний, високим $\epsilon$ рівень толерування суспільства неформальним практикам (починаючи від побутового рівня). Клієнтарно-патронатна мережа 
утворена довкола постаті глави держави; б) вірменська політична еліта узалежнена від груп тиску, які мають кланову природу; механізм оновлення еліт слабкий. На політиці позначається превалювання прихильності вірмен до таких неформальних структур, як сім'я або ж коло друзів. Сформована кланова групова ідентичність, а рівень корупції та патронату становлять загрозу національній безпеці; в) Грузія хоч і здійснила цивілізаційний прорив, але процес інституційних реформ не завершений: зберігаються топ-корупція, клановість, непотизм тощо (ймовірно, данина традиції «ахлобелі» («близькі люди»)); елементи патріархальної політичної культури позначаються на формах влади та субординації. Водночас змінюється інституційний дизайн (співвідношення формальних і неформальних інститутів).

Помітними є окремі відмінності між державами регіону. Вірменія впровадила процедуру декларування доходів, майна державних службовців, а Азербайджан блокує запуск цього антикорупційного механізму; Вірменія запроваджує механізми мінімізації корупційних ризиків в електоральному процесі, а Азербайджан практично не протидіє непрозорим схемам у виборчих кампаніях; в Азербайджані є президентська республіка (суперпрезиденціалізм), а Вірменія та Грузія переходять до парламентської республіки; політика Вірменії є конкуренцією кланів, представлених у парламенті, а в Азербайджані політика визначається главою держави та кланом, до якого належить він;

- неформальний політичний інституційний простір впливає на формування параметрів політичного процесу України від часу проголошення незалежності. Формальні правила незмінно підривалися неформальними, у результаті чого інституційними характеристиками нашої держави $\epsilon$ непотизм (кумівство), клієнтизм, патронатні відносини тощо. Зберігається присутність родинних зв'язків у зміцненні влади та корупції (т. зв. «фамілізація» за означенням «Freedom House»). Hе $\epsilon$ сконструйована інституційно розвинена державна архітектура; політична інституціалізація відбуває несистемно; керівна еліта схильна до вирішення питань за допомогою неформальних інститутів i практик; процес відтворення влади недостатньо підконтрольний суспільству; приватні бізнесінтереси та державна політика взаємно переплетені. Попри певне зростання демократичності та відкритості політичної системи, неформальні інститути продовжують домінувати над формальними, розвивається «кумівський капіталізм», клієнтарно-патронатні мережі конкурують між собою. Причину можна вбачати в значною мірою архаїчній соціальній організації, побудованій на неформальних клієнтелах, неписаних правилах, корупції, тіньовій економіці. Очевидною $\epsilon$ нагальність інституційного зміцнення держави та деконструкції неформальних інститутів.

Поза межами пострадянського простору неформальна інституціалізація політики також пропонує широкий емпіричний матеріал для аналізу. Вивчення контрастних за рівнем впливу на політику неформальних інститутів (латиноамериканських (Аргентина, Бразилія та Перу), азійських (найперше, південно-східних) держав, США та держав-учасниць $\mathrm{CC)} \mathrm{уможливило} \mathrm{низку} \mathrm{наших}$ висновків:

- латиноамериканський регіон $є$ зоною потужної активності неформальних підривних інститутів. Цьому сприяють довготривалі диктатури, i, як наслідок - незрілість демократії та толерування населенням таким механізмам. Латинська Америка є слабко інституціалізованим середовищем, в якому неформальні інститути заміщуючого типу (за класифікацією Г. Хелмке та С. Левітскі) заміняють у здійсненні завдань політики недієспроможні формальні інститути. Зокрема: а) Аргентина відзначається закритістю політичних інститутів, непрозорістю систем звітності, слабкою кадровою політикою, яка допускає сімейність і клановість. Очільники держави (М. Х. Сельман, Х. Д. Перон, І. Перон, К. Менем, Ф. де ла Руа, Н. Кіршнер, К. Ф. де Кіршнер та ін.) використовували корупційні, кланові та ін. неформальні механізми; б) неформальна інституціалізація в Бразилії укорінена від колоніальної епохи, коли великою була роль коронелізму як методу традиційного контролю еліт. В новітню епоху неформальні підривні інститути зберегли та наростили свою присутність у політиці, зросла кількість корупційних справ, зокрема за президентства Ж. Сарнея, Ф. Коллора ді Мелу, І. Франку, Ф. Е. Кардозу, Л. І. Лули да Сілви, Д. Русеф і т. д. Глави держави оголошували курс на протидію корупції і водночас самі ж були звинувачені у ній. Намагання провести швидкий антикорупційний «капітальний ремонт» країни водночас послаблює її політичну систему: існує широке громадське невдоволення устроєм держави, а політики обирають як стиль спілкування взаємні звинувачення, що не виключає прихід до влади антиелітарних популістів; в) у Перу протидія неформальній інституціалізації політики незмінно $є$ частиною курсу кожного глави держави. Водночас самі ж очільники не мають політичної волі, власним прикладом суперечачи популістських виголошеним намірам. Прикладом $\epsilon$ екс-президенти Перу А. Фухіморі та А. Толедо; 
- для азійського (найперше південноазійського регіону) притаманна виражена традиційна неформальна інституціалізація за одночасної появи ефективних механізмів протидії ій (як-от у Сінгапурі, Гонконгу). Особливо яскраво неформальна підривна інституціалізація проявляється у найбідніших країнах Азії, в яких диктаторські режими, побоюючись повалення, змушені спиратися на підтримку родинних кланів для посилення власної влади. Поширеним $є$ кронізм як «капіталізм для своїх». У більшості держав регіону (найперше, Філіппіни, Малайзія, Таїланд та ін.) протидія корупції активізується лише під час виборчих кампаній як частина популістської виборчої риторики або ж задля антиреклами електоральних конкурентів. Неформальна деструктивна інституціалізація є маркерами кланів Х. М. Сухарто (Індонезія), Ф. Маркоса та К. Акіно (Філіппіни), Ро Де У (Південна Корея), Т. Чинавата (Таїланд) та ін. Натомість найуспішніші антикорупційні стратегії обрані були Сінгапуром і Гонконгом (з опорою на жорстку політичну волю лідерів та відсутність імунітетів), а КНР зорієнтована на репресивну, але водночас малоефективну антикорупційну модель.

Неформальна інституціалізація у більшості держав регіону своїм корінням сягає доколоніального періоду. Наприклад, в Індонезії (у яванських королівствах) монарх розподіляв привілеї для «підгодовування» наближених, клієнтів, родичів; бюрократична посада була апанажем, який дозволяв тим, хто ії обіймав, використовувати свій статус в особистих матеріальних інтересах; результатом стала поява психології «через владу - до грошей», тобто виникло підгрунтя культури корупції;

- приклад США засвідчує: державами, які опираються на демократичні засади, з одного боку, не випрацювано механізми цілковитого запобігання неформальним деструктивним інститутам політики, а 3 іншого - ними впроваджуються дієві формати мінімізації їх руйнівного впливу. Упродовж історії держави в політиці були присутні клани (Рузвельтів, Кеннеді, Бушів та ін.), але у більшості випадків у кланах не простежувалася антидемократична суперечливість, бо процес приходу до влади нових представників відомих родин зазвичай відбувався 3 дотриманням законодавчо визначених процедур під контролем громадськості (Д. Трамп найбільше критикується за відхід від антинепотистської політики). Також відзначимо, що американська система протидії корупції не є досконалою, має прогалини, що уможливлює зловживання корупційного характеру (найперше, при фінансуванні виборчого процесу та партій, а також лобізму);

- аналіз політичного процесу держав-учасниць ЄС засвідчує значну увиразненість у них неформальної деструктивної інституціалізації. Найвищий ії рівень - у державах Південної Європи, а також в окремих державах Центральної та Східної Свропи (найперше, Румунії, Болгарії). Так, для держав Південної Свропи характерне толерування корупційним практикам, взаємини політиків із нелегальним бізнесом; різні підривні практики прирівняні до неформальних національних традицій. Ці держави непослідовні у протидії деструктивним інститутам, а жорсткі кампанії мають поодинокий характер (на взірець італійської спецоперації «Чисті руки», «Справи Гюртеля» проти іспанської Народної партії). Є зв'язок між затяжною фінансовою кризою (від 2008 року) та проблемами непрозорого управління державами Південної Європи зі застосуванням механізмів неформальної інституціалізації. Натомість у державах Північної Європи рівень неформальної інституціалізації деструктивного виду значно нижчий: ефективно спрацьовує протестантська етика, «скандинавська доброчесність» і принцип публічності влади; тут поєднуються довіра та контроль.

Вивчення неформальної інституціалізації у найрозвиненіших європейських державах (Велика Британія, ФРН, Франція) засвідчує, що їх не можна уважати державами з нульовою терпимістю до корупції, непотизму, кронізму тощо. Найчастішими $є$ проблеми, пов'язані зі стандартами доброчесності чиновників, політиків, механізмами антикорупційного убезпечення в політиці. Парламентський непотизм, надання місць у палаті лордів в обмін на великі пожертви, зроблені на партійні рахунки, нецільове витрачання державних коштів депутатами тощо залишаються проблемами сучасної Великої Британії. У ФРН фіксується корупція високопосадовців, незаконні схеми фінансування партій, непрозоре лобіювання (відсутній реєстр лобістів), зберігається неформальна традиція «дверей, що обертаються» (щодо топ-політиків, які завершили політичну кар'єри й одразу працевлаштувалися у великому бізнесі, де використовують напрацьовані зв'язки та репутаційний капітал). Давніми $є$ традиції неформальної інституціалізації й у Франції, де в монархічному середовищі зароджувалися традиції непотизму, фаворитизму тощо, а сьогодні фігурантами корупційних справ стають республіканські екс-президенти (Ж. Ширак, Н. Саркозі та ін.), кандидати в президенти (Ф. Фійон та ін.). Від 2017 року Франція реалізує інноваційні реформи, спрямовані проти сімейності у політиці, на жорсткішання фінансової звітності парламентарів, звуження умов консультаційної діяльності парламентарів тощо. 
Для держав-учасниць ЄС із регіону Центральної та Східної Свропи протидія неформальній інституціалізації «ускладнюється реліктами комуністичних режимів» [1, с. 311]. Обрана для аналізу неформальної інституціалізації Румунія є прикладом найвиразнішого та послідовного спротиву підривним практикам у політиці. Уже другий рік (2017-2018) національне громадянське суспільство в умовах гострої урядової кризи протистоїть прихильникам «старих правил гри» серед владної еліти, які мають намір зміни вектора демократичних перетворень (намагання провести амністію та декриміналізувати злочинів посадових осіб-корупціонерів, ліквідувати політичну незалежність спеціального антикорупційного органу в судовій сфері - Судової інспекції тощо).

Механізми запобігання та протидії неформальним деструктивним інститутам політики виступають певними алгоритмами реалізації як державної політики зі забезпечення прозорості політичного процесу, так і програмою інститутів громадянського суспільства, спрямованою на політичний контроль. Політичний механізм є гнучким інструментом, який задля дієвості може та має бути невідкладною відповіддю-реакцією на політичну динаміку. Основними групами механізмів у контексті дослідження є: запобіжні (превентивні, спрямовані на недопущення інституціалізації деструктивних неформальних інститутів політики); протидії (викорінення, мінімізація уже інституціалізованих неформальних практик у політиці).

Основним механізмом запобігання та протидії політичному непотизму, кронізму та фаворитизму уважаємо удосконалення законодавства в частині регулювання відносин зайнятості на державній, муніципальній та ін. службі. Це передбачає унормування вичерпного переліку осіб, працевлаштування, підтримка та просування яких може кваліфікуватися як прояв неформальної інституціалізації, а також визначення санкцій, які будуть вагомим стримувальним бар'єром (криміналізація відповідальності). До цієї ж групи механізмів можна віднести запровадження дієвого як державного, так і громадського контролю за службовою поведінкою посадовців і політиків щодо практикування ними непотизму, кронізму, фаворитизму тощо. Серед механізмів вкажемо на конструювання та затвердження «системи заслуг» (на взірець тієї, що діє у США), у якій чітко визначалися б критерії оцінювання професіоналізму кандидата на певну посаду; важливе значення мають максимально відкриті, прозорі конкурсні відбори. Наступний механізм лежить у площині політико-правової культури громадян, який полягає у формуванні нульової терпимості до неформальних деструктивних інститутів.

Механізми запобігання та протидії корупції, клановості в політиці лежать у площині співпраці влади (неодмінно зі сильною антикорупційною волею керівництва держави) та громадянського суспільства. Серед антикорупційних механізмів виділимо: впровадження максимальної прозорості влади; запровадження прозорого лобіювання; прийняття етичних кодексів (кодексів поведінки) парламентарів та ін. посадовців, політиків; нагляд держави та громадськості за прозорістю фінансування суб'єктів політики; недопущення практики «дверей, що обертаються» для ексвисокопосадовців; жорсткішання відповідальності (окремі держави навіть вдаються до авторитарної відміни для високопосадовців принципу презумпції невинуватості); максимальна незалежність антикорупційних органів; впровадження механізмів е-держави (як спосіб мінімізації бюрократичної корупції). Необхідне встановлення суспільної атмосфери цілковитого нетолерування корупції; неприпустимим $\epsilon$ використання посади, зв'язків тощо як неформальної підстави уникнення реального покарання за корупцію. Прихильність до цінностей правової, демократичної держави заперечує смертну кару за корупційні злочини (водночас у 13-ти державах вона існує, що водночас не впливає на зменшення кількості таких протиправних діянь з корупційною компонентою).

Механізми мінімізації клановості у політиці узалежнені від природи самих кланів (родові, політичні та ін.). Якщо клани $є$ компонентом традиціоналізму, архаїчності політики, інтегровані ментально, засновані на широкому розповсюджені родинних зв'язків у соціально-політичному житті, (як у центральноазійських державах), то протидія такій неформальній інституціалізації ускладнюється - модернізація суспільно-політичного життя є довготривалим процесом; механізми мінімізації такої клановості $\epsilon$, найперше, в площині політичної культури населення, загальної інтегрованості населення до системи новітніх демократичних цінностей. Якщо клани базуються на політико-економічних інтересах, то механізми протидії їм лежать, найперше, у площині ефективної правоохоронної та судової системи, а також системи антикорупційних заходів.

Загалом, уважаємо, необхідна системна протидія неформальній підривній інституціалізації політики через взаємопереплетіння різних деструктивних неформальних інститутів. Комплекс заходів, спрямований проти неформальної деструктивної інституціалізації, має поєднувати як репресивні, так і превентивні механізми, які мають лежати винятково в площині цінностей правової держави. 
Бібліографічний список:

1. Губрієнко О. Особливості політико-правових змін у країнах Центрально-східної Свропи (на прикладі Болгарії та Румунії). [Електронний ресурс]. - Режим доступу: http://www.stattionline.org.ua/filologiya/79/13419osoblivosti-politiko-pravovix-zmin-u-kra\% D1\%

2. Кушнарьов I. В. Політична корупція в умовах неоавторитаризму держав Центральної Азії (приклад Казахстану, Киргизстану та Таджикистану) / І. В. Кушнарьов // Вісник Дніпропетровського університету ім. Олеся Гончара. - Сер. : «Філософія. Соціологія. Політологія». - 2017. - № 2. - С. 4-16.

\section{Popazohlo V. S., Destructive informal political institutions: manifestations and mechanisms of counteraction}

The article investigates the destructive kinds of informal political institutions. It identifies their main types, such as political nepotism, cronyism, favoritism, corruption, patron-clientelism, clanism and others. The author proposes a new understanding of the main types of destructive informal political institutions through the prism of neo-institutionalism methodology and analyzes the main causes of the emergence and rooting of this type of institutions. As a result of the study of the informal destructive institutionalization in the post-Soviet area, the author concludes that the subversive type of institutions is clearly expressed in the countries of Central Asia, Southern Caucasus, Ukraine, Belarus and Russia, although there are certain characteristic features of each of the countries covered by this research. The study reveals the peculiarities of the informal institutionalization of politics in countries with different levels of destructive institutions' influence on politics: Latin American (Argentina, Brazil and Peru), Asian (mainly South-East Asian) countries, United States, and member states of the European Union. It identifies the following groups of mechanisms of counteracting the destructive institutionalization of politics: preventive (aimed at preventing the institutionalization of destructive informal political institutions); counteracting (eradication, minimization of already institutionalized informal practices in politics).

In the analysis, special attention is paid to the post-Soviet states. The article examines the manifestations of informal institutionalization in the countries of South Caucasus. It reveals the influence of subversive informal institutions on the political systems of Azerbaijan, Armenia and Georgia. The author indicates the main differences in the subversive institutions implementation in the countries of the region and defines the condition that promote or hinder the rooting of informal subversive institutions in the political system of the post-Soviet states of South Caucasus.

The article compares the informal political institutions of destructive kind in Belarus and Russia. It examines the common and distinctive characteristics of informal institutionalization in these countries. The subversive informal political institutions in Belarus and Russia demonstrate the following common characteristics: generally, the role of subversive informal political institutions is crucial in the politics of both countries; the destructive formal and informal political institutions not only are not in opposition to one other, but complement each other; neo-authoritarianism contributes to the development of informal practices in both countries; clanism exists in the management system, there are developed patron-client networks; informal client relationships dominate over the elements of civil society; the informal institutionalization manifests itself in the informal selection of candidates for offices; the elites are recruited of the basis of clientelism; the replacement of formal institutions with informal practices leads to the erosion of state institutes in both countries, weakens their resilience to various risks for the political system.

Key words: political institutions, informal destructive institutions, cronyism, corruption, clanism, favoritism, patron-clientelism. 